\title{
Penerapan Model Pembelajaran Treffinger Dan Ketrampilan Berpikir Divergen Mahasiswa
}

\author{
Yuswanti Ariani Wirahayu*, Hendri Purwito*, Juarti* \\ * Jurusan Geografi, Fakultas Ilmu Sosial, Universitas Negeri Malang
}

\begin{tabular}{l}
\hline INFO ARTIKEL \\
\hline Riwayat Artikel: \\
Diterima: $13-03-2017$ \\
Disetujui: $22-11-2017$
\end{tabular}

Kata kunci:

Model Pembelajaran;

Treffinger; Berpikir Divergen

\section{Alamat Korespondensi:}

Yuswanti Ariani Wirahayu

Jurusan Geografi

Universitas Negeri Malang

Jalan Semarang No. 5 Malang

E-mail: yuswanti.ariani.fis@um.ac.id

Abstrak: Model pembelajaran Treffinger merupakan salah satu dari sekian banyak model pembelajaran yang secara khusus mengembangkan kemampuan berpikir divergen. Dalam penelitian ini, model pembelajaran Treffinger digunakan dalam pembelajaran melalui teknik-teknik kreatif. Mulai dari teknik yang sederhana pada tingkat pertama hingga yang majemuk melalui pemecahan masalah kreatif pada tingkat ketiga. Kreativitas bagi mahasiswa merupakan salah satu sarana untuk aktualisasi diri. Berpikir divergen bersifat luas yang mencirikan kelancaran, keluwesan, dan kebaruan. Penelitian ini bertujuan menguji pengaruh model pembelajaran Treffinger terhadap kemampuan berpikir divergen mahasiswa. Penelitian dilakukan pada mahasiswa Program Studi S1 Geografi Fakultas Ilmu Sosial Universitas Negeri Malang Tahun 2016/2017 pada matakuliah Geografi Sosial. Subjek penelitian adalah mahasiswa angkatan 2016 kelas G sebagai kelas eksperimen dan kelas $\mathrm{H}$ sebagai kelas kontrol. Penelitian ini merupakan penelitian eksperimen semu (quasi experiment) dengan desain posttest Control Group Design. Variabel terikat dalam penelitian ini adalah berpikir divergen dan variabel bebasnya model pembelajaran Treffinger. Instrumen pengukuran kemampuan berpikir divergen menggunakan tes essay. Hasil pengukuran dianalisis menggunakan t-test dengan bantuan program SPSS 21.0 for Windows. Berdasarkan hasil analisis, rata-rata kemampuan berpikir divergen mahasiswa kelas eksperimen lebih tinggi dengan skor 80,72 dibandingkan dengan kelas kontrol yang memiliki skor 75,73. Hasil analisis uji-t menggunakan independen sample t-test diperoleh data $\mathrm{p}$ level $0,002>$ dari kecil dari $0,05(\mathrm{p}<0,05)$. Hasil perhitungan ini membuktikan bahwa model pembelajaran Treffinger berpengaruh terhadap kemampuan berpikir divergen mahasiswa. Jadi, dapat disimpulkan bahwa model pembelajaran Treffinger berpengaruh terhadap kemampuan berpikir divergen mahasiswa Geografi FIS Universitas Negeri Malang. 


\section{PENDAHULUAN}

Proses pembelajaran yang dilakukan pada umumnya ditentukan oleh peran guru atau dosen dan siswa atau mahasiswa sebagai individu yang terlibat langsung di dalam proses tersebut. Pembelajaran merupakan suatu proses yang rumit karena tidak sekedar menyerap informasi, tetapi juga melibatkan berbagai kegiatan dan tindakan yang harus dilakukan untuk mencapai tujuan. Guru atau dosen merupakan kunci dalam meningkatkan pendidikan, di mana yang bersangkutan bertanggung jawab untuk mengatur, mengarahkan, dan menciptakan suasana yang mendorong mahasiswa untuk melaksanakan kegiatan di kelas. Dalam proses pembelajaran terjadi hubungan timbal balik (interaksi) antara dosen dengan mahasiswa. Dalam interaksi tersebut dosen berperan sebagai pengajar atau motivator dan fasilitator dalam belajar. Dosen dituntut mampu menciptakan situasi pembelajaran yang kondusif, yaitu pembelajaran aktif, kreatif, inovatif, efektif dan menyenangkan dalam kegiatan proses pembelajaran. Situasi yang kondusif dapat membuat kegiatan pembelajaran tidak membosankan dan mahasiswa lebih mudah menyerap informasi yang diberikan. Secara tidak langsung kondisi tersebut dapat meningkatkan pemahaman, kreativitas, dan keaktifan mahasiswa dalam kelas yang akan berdampak pada hasil belajar.

Geografi Sosial merupakan salah satu matakuliah wajib di Jurusan Geografi Fakultas Ilmu Sosial Universitas Negeri Malang, yang diberikan pada semester 1, yang bertujuan untuk mendidik mahasiswa menjadi manusia yang dapat berpikir logis, kritis, dan rasional, serta dapat peranan dalam masyarakat. Pada umumnya mahasiswa semester pertama masih belum terbiasa dengan situasi, kondisi dan sistem belajar di perguruan tinggi, sehingga ada yang mengalami kesulitan menyesuaikan diri dengan sistem tersebut. Dampak ikutannya adalah mahasiswa sulit dalam memecahkan masalah yang merupakan salah satu tujuan matakuliah.

Kemampuan pemecahan masalah berarti kecakapan menerapkan pengetahuan yang diperoleh sebelumnya ke dalam situasi yang belum dikenal. Kemampuan memecahkan masalah sangat dibutuhkan oleh mahasiswa. Karena pada dasarnya mahasiswa dituntut untuk berusaha sendiri mencari pemecahan masalah serta pengetahuan yang menyertainya, menghasilkan pengetahuan yang benar-benar bermakna. Konsekuensinya adalah mahasiswa akan mampu menyelesaikan masalah serupa ataupun berbeda dengan baik karena mahasiswa mendapat pengalaman konkret dari masalah yang terdahulu (Trianto, 2007).

Memecahkan suatu masalah merupakan aktivitas dasar bagi manusia karena dalam menjalani kehidupan manusia pasti akan berhadapan dengan masalah. Apabila suatu cara atau strategi gagal untuk menyelesaikan sebuah masalah maka dapat dicoba dengan cara yang lain untuk menyelesaikannya. Suatu pertanyaan merupakan masalah apabila seseorang tidak mempunyai aturan atau hukum tertentu yang dengan segera dapat digunakan untuk menemukan jawaban dari pertanyaan tersebut. Membimbing mahasiswa untuk menyelesaikan masalah memungkinkan mahasiswa untuk menjadi lebih analitis dalam mengambil keputusan di dalam kehidupan. Dengan kata lain bila seorang mahasiswa dilatih untuk menyelesaikan masalah maka dia mampu mengambil keputusan sebab mempunyai keterampilan untuk mengumpulkan informasi yang relevan, menganalisis informasi, dan menyadari betapa perlunya meneliti kembali hasil yang telah diperoleh.

Menurut teori belajar yang dikemukakan Gagne bahwa keterampilan intelektual yang tinggi yang termasuk didalamnya yaitu penalaran dapat dilatih dan dikembangkan melalui pemecahan masalah atau problem solving. Pertanyaan disebut sebagai problem bagi mahasiswa jika tidak memiliki pengetahuan prasyarat sebelum mengerjakannya, mahasiswa belum mengetahui prosedur untuk memecahkan masalah. Namun apabila mahasiswa memiliki kemauan untuk menyelesaikan masalah, mahasiswa diperkirakan mampu menyelesaikan masalah. 
Model pembelajaran Treffinger merupakan cara untuk belajar kreatif, melalui tingkatan yang dimulai dengan unsur-unsur dasar ke fungsi-fungsi kreatif yang lebih kompeks. Langkah-langkah pembelajaran disusun dalam tiga tingkatan berisi teknik-teknik belajar kreatif. Tingkat I, teknik dasar berupa fungsi divergen, teknik kreatif yang digunakan adalah pertanyaan terbuka dan sumbang saran. Tingkat II, proses berpikir dan perasaan majemuk, teknik kreatif yang digunakan adalah analogi. Tingkat III, keterlibatan dalam tantangan nyata. Teknik kreatif yang digunakan adalah pemecahan masalah kreatif (Treffinger, 1980). Pengimplementasian model pembelajaran Treffinger dalam pembelajaran dilaksanakan berturut-turut dari tingkat pertama dilanjutkan tingkat kedua dan ketiga.

Model pembelajaran ini mempunyai keunggulan, yaitu: 1) model Treffinger didasarkan pada asumsi bahwa kreativitas adalah proses dan hasil belajar; 2) dilaksanakan kepada semua mahasiswa dalam berbagai latar belakang dan tingkat pengetahuan; 3) mengintegrasikan dimensi kognitif dan afektif dalam pengembangannya; 4) melibatkan secara bertahap kemampuan berpikir konvergen dan divergen dalam proses pemecahan masalah; 5) memiliki tahapan pengembangan yang sistematik, dengan berbagai macam metode dan teknik untuk setiap tahap yang dapat diterapkan secara fleksibel Treffinger (1980).

Model pembelajaran Treffinger dapat digunakan dalam bermacam-macam situasi. Model ini menggabungkan pemikiran secara kompleks sehingga dapat digunakan dalam mengembangkan pemikiran kritis dan kreatif. Berdasarkan hal tersebut berarti bahwa pembelajaran Treffinger efektif dalam melibatkan berpikir kreatif dan berpikir kritis. Model ini dapat membantu mahasiswa belajar dan mengembangkan ide baru menggunakan berpikir kreatif. Berpikir kreatif dapat dilihat dari beberapa tahapan yaitu fluency, flexibility, originality, dan elaboration.

Berdasaran hal tersebut berarti bahwa model pembelajaran ini memiliki sifat yang fleksibel serta melihat berpikir secara kompleks. Pada prosesnya model ini memperlihatkan keterkaitan antara berpikir kreatif dan kritis sehingga akan memperoleh hasil maksimal dalam mengembangan kemampuan berpikir divergen. Berpikir kreatif terjadi ketika ingin memunculkan banyak ide sedangkan ketika mengevaluasi berarti melatih berpikir kritis.

Dari berbagai model belajar kreatif yang ada, maka substansi model kreatif Treffinger dianggap paling reliabel, fisibel, dan aplikabel dalam pembelajaran (Supriyono, 2011). Jadi dapat disimpulkan bahwa model pembelajaran Treffinger memiliki kesuksesan yang baik dalam mengajarkan berpikir divergen. Hal ini karena berbagai pengetahuan dan keterampilan yang diperoleh dari pembelajaran bukan hanya angan-angan tetapi mengharuskan mahasiswa menerapkan di kehidupan melalui pembuatan perencanaan. Sehingga dapat dikatakan juga bahwa model pembelajaran Treffinger ini memiliki relevansi tinggi dengan kehidupan mahasiswa.

Menurut Fasko (2000) bahwa "model pembelajaran Treffinger yang terdiri dari tiga level: fungsi divergen, proses berpikir dan perasaan kompleks, keterterlibatan pada tantangan nyata merupakan model yang memandang kreativitas merupakan perpaduan antara proses kognitif dan afektif'. Menurut Houtz and Krug (dalam Fasko, 2000) bahwa "kreativitas mempertimbangkan usaha-usaha yang melibatkan aspek kognitif dan afektif'. Teori ini melihat berpikir merupakan proses konstruksi, ketika individu berpikir maka sebenarnya individu sedang mengkonstruk pengetahuan. Melalui tiga level tersebut mengakibatkan mahasiswa terlibat pada berbagai kegiatan yang menantang dan memotivasi. Tantangan berfungsi memotivasi dari dalam diri mahasiswa yang merupakan bagian dari proses afektif. Sedangkan suasana belajar kreatif merupakan pemicu bagi timbulnya motivasi yang berasal dari luar diri mahasiswa. 
Penerapan model Treffinger di sekolah atau perguruan tinggi mencakup semua segi kegiatan baik pemecahan konflik sampai dengan pengembangan teori ilmiah (Munandar, 2009). Model ini juga telah terbukti efektif dalam mengembangkan kreativitas siswa (Pomalato, 2006; Siswati, 2011; Haryono, 2009). Jadi, dapat dikemukakan bahwa model ini memberikan kesempatan kepada mahasiswa dalam mengembangkan kreativitasnya melalui kondisi atau suasana lingkungan yang mendukung. Hal ini sejalan dengan pendapat Hayes (dalam Fasko, 2000) bahwa kreativitas dapat ditingkatkan dengan beberapa cara: (1) mengembangkan pengetahuan dasar; (2) menciptakan atmosfer yang tepat untuk kreativitas; (3) mencari analogi.

Selain berbagai pendapat tersebut, perlu diungkapkan juga beberapa pendapat mengenai teknik yang digunakan dalam model pembelajaran Treffinger. Olson (1996) menyatakan bahwa teknik sumbang saran melalui pertanyaan terbuka mendorong timbulnya banyak gagasan dengan harapan bahwa gagasan tersebut dapat menghasilkan gagasan yang kreatif. Pertanyaan terbuka dan menantang dapat merangsang mahasiswa membentangkan imajinasi dan cakrawala (Munandar, 2009). Hal ini dikarenakan teknik sumbang saran berusaha menghilangkan hal-hal yang menghambat munculnya gagasan yang merupakan bagian penting dari berpikir divergen. Sumbang saran juga menerima segala bentuk gagasan dari semua mahasiswa. Selain itu, penggunaan pertanyaan terbuka memberi kebebasan kepada mahasiswa untuk berani dalam mengemukakan gagasan sebanyak mungkin.

Teknik berikutnya adalah analogi, yang menawarkan cara yang sesuai dalam menemukan cara baru untuk memandang situasi lalu menunggu datangnya inspirasi (de Bono, 2009). Teknik ini melatih mahasiswa berpikir yang tidak biasa dalam memahami fenomena dengan harapan dapat memunculkan gagasan-gagasan yang beraneka ragam dan orisinil berdasarkan sudut pandang yang di luar kebiasaan. Melalui analogi, mahasiswa akan lebih mudah memahami permasalahan apabila mereka megetatahui permasalahan tersebut memiliki kesamaan dengan objek lain di sekitarnya yang sudah dikenal.

Selanjutnya adalah teknik pemecahan masalah kreatif. Mahasiswa pada tahap ini secara mandiri melatih pikirannya untuk menganalisis permasalahan, menguraikan hingga menemukan gagasan-gagasan dalam pemecahan masalah lalu mempertegas dalam rincianrincian tindakan. Melalui kegiatan pemecahan masalah tersebut akan meningkatkan sensitifitas mahasiswa terhadap permasalahan. Salah satu yang mencirikan berpikir divergen yaitu problem sensitivity (kepekaan terhadap masalah). Jadi, dapat disimpulkan bahwa teknik dalam model pembelajaran Treffinger ini memang ditujukan untuk mengajarkan berpikir divergen, baik dari segi pemunculan gagasan sebanyak mungkin, analogi, ataupun pemecahan masalah kreatif yang selanjutnya teknik tersebut dikemas dalam satu wadah yakni model pembelajaran.

Sejalan dengan kelebihan model pembelajaran Treffinger dalam mengembangkan kemampuan berpikir divergen, Williyatimas (2005) menemukan bahwa ada perbedaan yang signifikan antara kemampuan berpikir kreatif siswa yang memperoleh pembelajaran model Treffinger dengan kemampuan kreatif siswa yang memperoleh pembelajaran biasa. Penelitian ini juga menunjukkan bahkan siswa dengan taraf sekolah rendah juga mengalami peningkatan yang signifikan dalam kemampuan berpikir kreatifnya. Hal ini mengindikasikan bahwa model pembelajaran Treffinger memang unggul dalam mengembangkan pemikiran divergen dengan melibatkan proses kognitif dan afektif melalui proses diskusi pemecahan masalah. Proses tersebut dapat membangkitkan potensi kreatif yang dimiliki oleh mahasiswa.

Model Treffinger sangat efektif dalam meningkatkan unsur kemampuan berpikir kreatif (divergen) anak. Berdasarkan temuan tersebut maka keistimewaan model pembelajaran Treffinger yaitu terletak pada kemampuannya dalam meningkatkan 
kemampuan berpikir divergen. Kemampuan berpikir divergen meliputi kelancaran, keluwesan, keaslian, dan kerincian. Selain ditemukan juga bahwa sikap kreatif berkembang seiring berkembang kemampuan kreatifnya. Peningkatan ini dapat dipahami karena melalui perlakuan yang disengaja dalam proses belajar kreatif dalam mengembangkan dimensi kognitif secara tidak langsung juga akan mendorong peningkatan pada sikap kreatifnya. Dengan demikian dapat dikatakan bahwa model pembelajaran Treffinger secara efektif dalam meningkatkan sikap kreatif mahasiswa sejalan dengan peningkatan kemampuan berpikir kreatifnya.

Berdasarkan berbagai pendapat tentang kelebihan model pembelajaran Treffinger seperti yang telah diuraikan di atas, kelebihan model ini terletak pada bagaimana model ini memadukan antara proses berpikir. Berpikir divergen bersifat luas yang mencirikan kelancaran, keluwesan, dan kebaruan. Adanya ciri tersebut tersebut membuat model ini dirasa efektif dalam mengembangkan berbagai kemampuan berpikir divergen. Hal inilah yang menjadikan landasan dilakukannya penelitian eksperimen pengaruh model pembelajaran Treffinger terhadap kemampuan berpikir divergen mahasiswa Jurusan Geografi.

The Northeast Regional Education Laboratory USA (dalam Sumarmi, 2012) mengungkapkan bahwa salah satu hal yang harus diperhatikan dalam mengembangkan pembelajaran geografi yang kontekstual adalah mahasiswa diajak menggunakan kemampuan berpikir tingkat tinggi seperti kemampuan berpikir kritis, analitis, dan kreatif. Berdasarkan hal tersebut, maka pembelajaran geografi di Perguruan Tinggi hendaknya membiasakan melatih mahasiswanya untuk berpikir tingkat tinggi melalui berbagai kegiatan menganalisis fenomena geosfer secara kontekstual di lingkungan sekitar mahasiswa. Berpikir divergen merupakan salah satu bentuk dari berpikir tingkat tinggi tersebut.

Seperti halnya pembelajaran geografi lainnya, matakuliah Geografi Sosial melibatkan tiga pendekatan geografi dalam menganalisis fenomena geosfer yang meliputi pendekatan keruangan, kelingkungan, dan kompleks wilayah. Ketiga pendekatan ini saling berkaitan dalam mempelajari suatu fenomena aktivitas sosial yang terjadi dalam suatu ruang. Pendekatan keruangan memperhatikan penyebaran penggunaan ruang yang telah ada dan penyediaan ruang untuk berbagai kegiatan, pendekatan kelingkungan mempelajari interaksi antara organisme hidup dengan lingkungan, dan pendekatan kompleks wilayah mempelajari interaksi wilayah karena perbedaan karakteristik wilayah satu dengan yang lain. Berdasarkan uraian pada latar belakang tersebut, maka dapat pertanyaan penelitian dirumuskan; Apakah penerapan model pembelajaran Treffinger berpengaruh terhadap ketrampilan berpikir devergen mahasiswa.

\section{METODE}

Penelitian ini bertujuan untuk mendeskripsikan pengaruh penerapan model pembelajaran Treffinger terhadap ketrampilan berpikir divergen mahasiswa. Berdasarkan tujuan penelitian, maka penelitian ini menggunakan rancangan eksperimen semu (quasi experiment) dengan Posttest Control Design. Subjek penelitan terdiri dua kelas, kelas eksperimen dan kelas kontrol. Kelas eksperiment diberikan perlakuan berupa pembelajaran dengan menerapkan model Treffinger sebanyak 2 (dua) kali, sementara kelas kontrol diberikan pembelajaran menggunakan model pembelajaran seperti biasanya, ceramah dan tanya jawab.

Subjek penelitian ini adalah mahasiswa peserta matakuliah Geografi Sosial pada Jurusan Geografi FIS UM pada semester Gasal 2016-2017. Penentuan dan pemilihan kelas dilakukan secara random karena dianggap mempunyai kemampuan akademis sama, berdasar hasil seleksi masuk perguruan tinggi, sehingga dianggap homogen. Yang terpilih sebagai 
kelas eksperimen adalah kelas $\mathrm{G}$ angkatan 2016, sedangkan yang menjadi kelas kontrol adalah kelas H angkatan 2016 Program Studi Geografi Fakultas Ilmu Sosial Universitas Negeri Malang.

Kegiatan penelitian ini bertujuan mengukur kemampuan berpikir devergen mahasiswa peserta matakuliah Geografi Sosial. Secara umum, perlakuan yang dilakukan dibagi menjadi beberapa tahap.

1. Tahap Pertama, dilakukan observasi terbatas untuk memperoleh informasi tentang kondisi dalam pembelajaran, jumlah mahasiswa (subjek) yang terlibat dalam penelitian, jadwal pelaksanaan, hasil belajar, untuk selanjutnya menentukan subjek penelitian.

2. Tahap Kedua, memberikan perlakuan pada kelas yang telah terpilih, yaitu kelas eksperimen diberi perlakuan menggunakan model pembelajaran Treffinger.

3. Tahap Ketiga, diberikan post-test. Hasil post test ini digunakan untuk mengetahui kemampuan berpikir divergen mahasiswa setelah dilaksanakan pembelajaran. Berdasarkan nilai ini, selanjutnya dilakukan analisis dan mendeskripsikan pengaruh model pembelajaran Treffinger terhadap kemampuan berpikir divergen mahasiswa. Perlakuan penelitian berpa penerapan model Treffinger dilakukan sebanyak 2 (dua) kali pertemuan dengan tiap pertemuan selama 2 x 50 menit. Post test dilakukan di luar jam pembelajaran dengan alokasi waktu 70 menit untuk 5 soal esaay. Instrumen berupa tes terdiri dari butir soal yang mewakili tujuan pembelajaran dan indikator yang diukur.

Penelitian ini merupakan penelitian kuantitatif sehingga analisis data yang digunakan untuk mengolah data dalam penelitian menggunakan metode statistik. Teknik analisis yang digunakan untuk mengetahui pengaruh pembelajaran model Treffinger terhadap ketrampilan berpikir divergen mahasiswa adalah dengan uji beda atau uji-t dengan taraf signifikansi 5\%. Perhitungan uji-t dalam penelitian ini dilakukan dengan SPSS 21.00 for Windows.

\section{HASIL DAN PEMBAHASAN}

Penelitian pengaruh penerapan model pembelajaran Treffinger terhadap ketrampilan berpikir divergen mahasiswa ini dilakukan pada matakuliah Geografi Sosial Program Studi Geografi angkatan tahun 2016. Istilah lain dari berpikir divergen ialah berfikir kreatif (creative thingking), berpikir imajiner (imaginative thingking), berpikir asli (original). Salah satu ciri dari orang yang berpikir kreatif atau mampu berpikir divergen adalah mampu menanggapi pertanyaan yang diajukan serta cenderung memberi jawaban lebih banyak. Dalam teori konstruktivistik, proses pembelajaran diartikan sebagai kreativitas dalam menata serta menghubungkan pengalaman dan pengetahuan sehingga membentuk suatu keutuhan. Pengkategorian kemampuan berpikir divergen didasarkan pada pedoman penilaian yang berlaku di Universitas Negeri Malang saat ini.

Setelah pembelajaran dilakukan sebanyak 2 (dua) kali pertemuan, dilakukan tes kemampuan berpikir divergen. Soal berbentuk essey sebanyak 4 (empat) soal yang setiap soalnya mengukur indikator kemampuan berpikir divergen mahasiswa. 
Tabel 1. Kemampuan Berpikir Divergen Mahasiswa

\begin{tabular}{ccccccc}
\hline \multirow{2}{*}{ No } & \multicolumn{2}{c}{ Nilai } & \multicolumn{2}{c}{ Kelas Kontrol } & \multicolumn{2}{c}{ Kelas Eksperimen } \\
\cline { 2 - 7 } & Angka & Huruf & f & $\%$ & f & $\%$ \\
\hline 1 & 60 & C & 5 & 12,20 & 0 & 0,00 \\
2 & 65 & B- & 2 & 4,88 & 0 & 0,00 \\
3 & 70 & B & 8 & 19,51 & 3 & 7,14 \\
4 & 75 & B & 5 & 12,20 & 9 & 21,43 \\
5 & 80 & A- & 10 & 24,39 & 11 & 26,19 \\
6 & $\geq 85$ & A & 11 & 26,82 & 19 & 45,24 \\
\hline \multicolumn{7}{c}{ Nilai Rata-rata } \\
\hline
\end{tabular}

Berdasarkan Tabel 1 diketahui bahwa rata-rata kemampuan berpikir divergen mahasiswa kelas eksperimen lebih tinggi dibandingkan dengan kelas kontrol. Pada kelas kontrol ditemukan ada nilai $\mathrm{C}+$ sementara yang mendapat nilai A sebanyak $26,82 \%$. Sedangkan pada kelas eksperimen kemampuan berpikir divergen mahasiswa minimal berada pada nilai B, dan nilai A sebanyak 45,24\%.

Indikator kemampuan berpikir divergen pada penelitian ini terdiri dari 4 (empat) indikator, yaitu: kemampuan berpikir lancar, kemampuan berpikir luwes, kemampuan berpikir orisinil serta kemampuan merinci. Keempat kemampuan ini diukur menggunakan test. Pada kelas eksperimen rata-rata pencapaian indikator berpikir lancar termasuk dalam kategori sangat baik dan merupakan indikator kemampuan dengan kategori paling banyak. Sedangkan pencapaian indikator kemampuan lainnya termasuk pada kategori sedang. Pada kelas kontrol, pencapaian indikator kemampuan berpikir lancar memiliki kategori paling tinggi pencapaiannya, sedangkan kemampuan berpikir orisinal paling rendah yaitu pada kategori kurang. Rata-rata skor pada masing-masing indikator baik kelas eksperimen maupun kelas kontrol dapat dilihat pada Tabel 2.

Tabel 2. Nilai Rata-rata Indikator Kemampuan Berpikir Divergen

\begin{tabular}{llll}
\hline Kelas & Indikator & Nilai & Kategori \\
\hline \multirow{4}{*}{ Eksperimen } & Berpikir lancar & 88,8 & Sangat Baik \\
& Berpikir Luwes & 72,3 & Sedang \\
& Berpikir Orisinil & 74,1 & Sedang \\
& Merinci & 71,7 & Sedang \\
\hline \multirow{4}{*}{ Kontrol } & Berpikir lancar & 73,1 & Sedang \\
& Berpikir Luwes & 67,2 & Kurang dari Sedang \\
& Berpikir Orisinil & 52,5 & Kurang \\
& Merinci & 62,5 & Lebih dari Cukup \\
\hline
\end{tabular}

Berdasarkan pada rumusan masalah yang telah dipaparkan pada bagian sebelumnya yaitu "Apakah penerapan model pembelajaran Treffinger berpengaruh terhadap ketrampilan berpikir devergen mahasiswa?", maka analisis yang digunakan untuk menjawab permasalahan penelitian tersebut adalah uji beda atau t-tes. 
Tabel 3. Hasil Analisis t-tes

\begin{tabular}{|c|c|c|c|c|c|c|c|c|c|c|}
\hline & & $\begin{array}{l}\text { Levene } \\
\text { for Equ } \\
\text { Varian }\end{array}$ & $\begin{array}{l}\text { Test } \\
\text { lity of } \\
\text { s }\end{array}$ & t-test for & Equality & f Means & & & $\begin{array}{l}95 \% \\
\text { Confic } \\
\text { Interv } \\
\text { Differ }\end{array}$ & $\begin{array}{l}\text { ence } \\
\text { lof the } \\
\text { nt }\end{array}$ \\
\hline & & $\mathrm{F}$ & Sig. & $\mathrm{t}$ & df & $\begin{array}{l}\text { Sig. } \\
(2- \\
\text { tailed })\end{array}$ & $\begin{array}{l}\text { Mean } \\
\text { Differenc } \\
\text { e }\end{array}$ & $\begin{array}{l}\text { Std. Error } \\
\text { Differenc } \\
\mathrm{e}\end{array}$ & Lower & Upper \\
\hline \multirow[b]{2}{*}{ Nilai } & $\begin{array}{l}\text { Equal } \\
\text { variances } \\
\text { assumed }\end{array}$ & \multirow[b]{2}{*}{12,906} & \multirow[b]{2}{*}{,001 } & $-3,250$ & 80 & ,002 & $-5,12195$ & 1,57506 & $\begin{array}{c}- \\
8,2582 \\
1\end{array}$ & $\begin{array}{c}- \\
1,9857 \\
0\end{array}$ \\
\hline & $\begin{array}{l}\text { Equal } \\
\text { variances } \\
\text { not } \\
\text { assumed }\end{array}$ & & & $-3,250$ & 65,914 & ,002 & $-5,12195$ & 1,57506 & $\begin{array}{c}- \\
8,2685 \\
3\end{array}$ & $\begin{array}{c}- \\
1,9753 \\
7\end{array}$ \\
\hline
\end{tabular}

Berdasarkan hasil perhitungan dengan uji beda atau t-tes seperti yang tertera pada Tabel 3 didapatkan hasil (sig. 2 tail) adalah $0,002 \leq$ dari 0,05 (pada $\alpha 0,05$ ). Dengan demikian berarti metode pembelajaran Treffinger berpengaruh terhadap kemampuan berpikir divergen mahasiswa.

\section{HASIL DAN PEMBAHASAN}

Hasil analisis data menunjukkan bahwa terdapat perbedaan kemampuan berpikir divergen antara kelas eksperimen dengan kelas kontrol. Temuan ini menunjukkan bahwa pembelajaran dengan menggunakan model Treffinger berpengaruh positif terhadap kemampuan berpikir divergen mahasiswa. Temuan ini sejalan dengan penelitian sebelumnya yang menyatakan bahwa model pembelajaran Treffinger efektif memberikan pengaruh yang nyata terhadap kemampuan berpikir keatif (Pomalato, 2006; Juwarsa, 2001; Williyatimas, 2005; Irmatun, 2009). Hasil analisis juga menunjukkan bahwa kemampuan berpikir divergen mahasiswa yang paling baik apa pada indikator berpikir luwes. Hal ini menguatkan penelitian sebelumnya bahwa model pembelajaran Treffinger mampu meningkatkan kemampuan berpikir kreatif (Siswati, 2011; Hariyono, 2009).

Pengaruh model pembelajaran Treffinger terhadap kemampuan berpikir divergen mahasiswa diduga kuat disebabkan oleh karaktristik model yang terdapat pada setiap teknik yang digunakan dalam langkah penerapan model. Masing-masing teknik diduga memiliki keunggulan dalam meningkatkan tiap indikator berpikir divergen. Hal ini dapat dilihat dari hasil analisis tentang keempat indikator berpikir divergen didapati bahwa keempat indikator berbeda antara kelas kontrol dan kelas ekperimen. Hal ini sejalan dengan pendapat Torrance (1980) bahwa "meskipun kreativitas terletak pada kemampuan menghasilkan sesuatu yang baru, tetapi kemampuan ini tidak bisa dilepaskan dengan kemampuan yang lain, yakni kelancaran dalam berpikir, kelenturan dalam memainkan gagasan, serta kemampuan mengelaborasi atau merinci gagasan itu dalam tindakan operasional".

Teknik kreatif yang digunakan pada model pembelajaran Ttreffinger meliputi teknik dasar (pertanyaan terbuka dan sumbang saran), teknik analogi, dan teknik pemecahan masalah kreatif. Teknik tersebut menggambarkan tingkatan dalam belajar kreatif dari yang dasar hingga yang kompleks. Hal ini sejalan dengan pengembangan kreativitas menurut Hayes (dalam Solso, 2007) bahwa "kreativitas dapat ditingkatkan dengan beberapa cara: 1) mengembangkan pengetahuan dasar; 2) menciptakan atmosfer yang tepat untuk kreativitas; 
3) mencari analogi”. Salah satu cara melatih kemampuan berpikir kreatif juga dengan memberikan pengalaman dalam penyelesaian masalah.

Dalam tindak kreatif tersebut mahasiswa pada dasarnya merupakan subjek pemberi makna. Dalam proses pembelajaran, sebaiknya dosen atau guru tidak menggurui melainkan secara adaptif berusaha memahami jalan pikiran mahasiswa untuk kemudian menampilkan sejumlah kemungkinan sehingga diajak berpikir divergen.

Berpikir divergen adalah kemampuan menemukan banyak kemungkinan jawaban terhadap suatu masalah dengan penekanan pada kuantitas, ketepatgunaan, dan keragaman jawaban berdasarkan data dan informasi yang tersedia. Berpikir divergen juga merupakan kemampuan dalam mengkonstruksi berbagai respon, ide, opsi, atau berbagi macam alternatif untuk suatu masalah atau tantangan. Berdasarkan hal tersebut berarti berpikir divergen adalah kemampuan berpikir yang menekankan pada penemuan alternatif jawaban, ide, opsi atau respon terhadap suatu permasalahan atau tantangan.

Orang dapat berpikir, meskipun kegiatan berpikir tidak dapat diamati secara langsung. Berfikir adalah aktivitas psikis yang bertujuan untuk memecahkan masalah sehingga mampu menemukan hubungan antar konsep. Proses berpikir menurut pandangan psikologi kognitif melibatkan proses menyesuaikan skemata dengan objek, menggunakan skemata untuk memberi respon dan memecahkan masalah, dan membangun serta menyusun skemata baru.

Selanjutnya dikemukakan bahwa skemata merupakan alat berpikir di mana seseorang menyimpan, mengatur, dan menggunakan kembali apa-apa yang dipelajari. Skemata menunjuk pada segala sesuatu yang bersifat pikiran dan perilaku yang dapat disimpan dan diulang serta digeneralisasikan dalam tindakan. Berpikir adalah proses yang dinamis yang dapat dilukiskan menurut proses atau jalannya, Proses atau jalannya berpikir pada dasarnya ada tiga langkah, yaitu 1) pembentukan pengertian; 2) pembentukan pendapat; dan 3) penarikan kesimpulan.

Menurut Munandar (2009) berpikir divergen adalah kemampuan berpikir berdasarkan data atau informasi yang tersedia untuk menemukan banyak alternatif jawaban terhadap suatu masalah, di mana penekanannya adalah pada kuantitas, ketepatgunaan dan keragaman jawaban. Senada dengan hal tersebut, Haryanto (2006) mengemukakan bahwa berpikir divergen adalah berpikir secara sistematik (system thinking) yang memusatkan pada bagaimana sesuatu berinteraksi dengan unsur-unsur pokok (constituent) lain dalam suatu sistem, serangkaian elemen berinteraksi untuk menghasilkan suatu keutuhan. Lebih lanjut Haryanto (2006) juga menyatakan bahwa cara berpikir divergen secara umum mcmiliki karakteristik; (a) lateral, artinya mcmandang suatu pcrsoalan dari beberapa sisi, (b) divergen menyebar ke berbagai arah untuk menentukan banyak jawaban, (c) holistik dan sistemik, bersifat menyeluruh (global), (d) intuitif imajinatif, (e) independen, (f) tidak teramalkan (unpredictable).

Cara berpikir divergen sangat penting untuk dikembangkan dalam pembelajaran. Berpikir divergent memberikan efek dorongan yang unik pada pemecahan masalah yang kreatif, yang tidak dapat dikontribusi oleh kecerdasan ataupun keahlian.

\section{KESIMPULAN}

Berdasarkan hasil analisis data dan pembahasan hasil penelitian dapat disimpulkan bahwa penggunaan model pembelajaran Treffinger memberikan pengaruh terhadap kemampuan berpikir divergen mahasiswa. Hal ini dibuktikan dengan hasil perhitungan analisis uji t mengunakan independen sample t test diperoleh data $\mathrm{p}$-level lebih kecil dari $0,05(\mathrm{p}<0,05)$ yaitu 0,002. Rata-rata kemampuan berpikir divergen kelas eksperimen lebih tinggi dibandingkan kelas kontrol. Hal tersebut disebabkan oleh langkah-langkah model 
pembelajaran Treffinger yang di dalamnya terdapat teknik-teknik belajar kreatif dari yang sederhana sampai yang kompleks.

Berdasarkan kesimpulan dari hasil penelitian ini maka penulis memberikan saran sebagai berikut:

1) Bagi dosen, penerapan model pembelajaran ini dapat dilakukan sebagai alternatif model untuk mengembangkan kemampuan berpikir divergen mahasiswa. Disarankan untuk a) memberikan alokasi waktu yang lebih banyak untuk setiap teknik pengembangan berpikir divergen, terutama pada tingkat ke III; b) memahami lebih baik tiap teknik kreatif terutama teknik analogi sebelum menerapkannya; c) sebaiknya berlatih dahulu dalam menghasilkan gagasan dan membuat penalarannya sebelum menerapkan model ini; d) membuat pedoman bagaimana merinci gagasan dari berbagai literatur; serta e) menerima semua gagasan mahasiswa.

2) Disarankan juga dilakukan penelitian lebih lanjut untuk: a) menguji pengaruh model pembelajaran Treffinger terhadap variabel lain dan pada lokasi, jenjang pendidikan, atau materi lain; serta b) mengintegrasikan atau membandingkan dengan model pembelajaran yang lain.

\section{DAFTAR RUJUKAN}

De Bono, Edward. 2009. Lateral Thinking (Berpikir Lateral). Alih bahasa oleh Sutoyo. Jakarta: Airlangga.

Fasko, Daniel. Jr. 2000. Education and Creativity. Creativity Journal Bowling Green State University. Vol. 13, Nos. 3 \& 4, 317-327.

Haryono, Ary Dwi. 2009. Pembelajaran Model Treffinger Untuk Menumbuhkan Kreeativitas Dalam Pemecahan Masalah Operasi Hitung Pecahan Siswa Kelas V SD Islam Bani Hasyim Singosari Malang. Tesis. Tidak Diterbitkan. Malang: Program Pascasarjana UM.

Munandar, S.C. Utami. 2009. Mengembangkan Bakat dan Kreativitas Anak Sekolah. Petunjuk Bagi Para Guru dan Orang Tua. Jakarta: PT Gramedia Widiasarana Indonesia.

Olson, Robert W. 1996. The Art of Creative Thinking (Seni Berpikir Kreatif).Alih bahasa oleh Alfonsus. Jakarta: Airlangga.

Pomalato, Sarson W.Dj. 2006. Mengembangkan Kreativitas Matematik Siswa dalam Pembelajaran Matematika Melalui Pendekatan Model Treffinger. Mimbar Pendidikan, No. 1/XXV, hal.22-25.

Siswati, Anna. 2011. Meningkatkan Kemampuan Berpikir Kreatif Matematika Melalui Pembelajaran Model Treffinger Pada Siswa Kelas VII SMPN 1 Singosari. Tesis. Tidak Diterbitkan. Malang: Program PascaSarjana UM.

Solso, Robert L. et,al. 2008. Psikologi kognitif. Jakarta : Penerbit Erlangga

Sudiarta. 2005. Pengembangan Kompetensi Berpikir Divergen Kritis Melalui Pemevahan Masalah Open-Ended.Jurnal Pendidikan dan Pengajaran IKIP Negeri Singaraja, Edisi Juli 2005.

Supriyono dan Hardika. 2011. Model Pembelajaran Transformatif Berbasis Learning How to Learn: Pengembangan dan Uji evektifitas Model untuk Peningkatan Kreativitas Belajar Mahasiswa dalam Mengeksplorasi Kompetensi Akademik untuk Kehidupan. Laporan Penelitian. Malang: LP2M UM Malang.

Trianto. 2007. Model Pembelajaran Inovatif Beorientasi Konstruktivisme. Jakarta: Prestasi Pustaka Publisher

Treffinger, D.J. 1980. A Preliminary Models of Creative Learning. Texas: Prufrock Press Inc 
Jurnal Pendidikan Geografi, Tahun 23, Nomor 1, Jan 2018 , Hal 30-40

Williyatimas. 2005. Penerapan Model Pembelajaran Treffinger Dalam Pembelajaran Matematika Untuk Meningkatkan Kemampuan Kreatif dan Kemampuan Pemecahan Masalah Siswa Kelas II SMP Ditinjau dari Peringkat Sekolah. Desertasi. Bandung: Pascasarjana UPI. 